DOI: $10.18276 /$ sip.2016.43/3-35

\title{
Sławomir Smyczek*
}

Uniwersytet Ekonomiczny w Katowicach, Wydział Zarządzania, Katowice, Polska

\section{WIEDZA FINANSOWA A ANALFABETYZM KONSUMENCKI NA RYNKU USŁUG FINANSOWYCH}

\begin{abstract}
Streszczenie
W artykule została podjęta próba identyfikację poziomu wiedzy finansowej konsumentów w Polsce. Przeprowadzone badania pozwalają stwierdzić, że poziom wiedzy finansowej konsumentów jest niski, a wręcz znaczną część polskich konsumentów cechuje analfabetyzm finansowy. Świadczy o tym fakt, iż decyzje finansowe konsumenci podejmują głównie na podstawie informacji nieformalnej. Zdecydowanie rzadziej korzystają z rzetelnych i obiektywnych informacji finansowych płynących z rynku, które wymagają jednak większego poziomu wiedzy i umiejętności finansowych. Konsumenci nie znają regulacji prawnych dotyczących poszczególnych usług finansowych. Poziom analfabetyzmu finansowego kontrastuje z subiektywną opinią konsumentów o ich dużej wiedzy o instytucjach finansowych i oferowanych przez nie usługach.
\end{abstract}

Sława kluczowe: wiedza finansowa, analfabetyzm finansowy, usługi finansowe

\section{Wstęp}

Usługi finansowe stały się we współczesnej gospodarce podstawowym czynnikiem gwarantującym rozwój społeczno-gospodarczy każdego kraju oraz poprawę jakości życia społeczeństwa. Dla każdego współczesnego konsumenta stają się niezbędnym elementem życia. Ułatwiają jego funkcjonowanie w społeczeństwie oraz

\footnotetext{
Adres e-mail: slawomir.smyczek@ue.katowice.pl.
} 
stwarzają odpowiednie warunki do rozwoju i odpoczynku. Dzięki usługom finansowym konsumenci mogą żyć wygodniej i bezpieczniej. Usługi finansowe ułatwiają przepływ środków pieniężnych i zaczynają być obecne prawie we wszystkich sferach życia konsumenta. Jednak jego wiedza o tych usługach i samym rynku usług finansowych, zachodzących na nim bardzo dynamicznie procesach oraz pojawiających się nowych zjawiskach są dalece niewystarczające.

Zmiany instytucjonalne, wprowadzenie ciągle nowych usług finansowych, a także coraz agresywniejsze próby oddziaływania na konsumenta sprawiają, że czują się oni często zdezorientowani i bezradni. Problemy te potęguje na rynku usług finansowych analfabetyzm finansowy konsumentów. Mając na uwadze powyższe, za zasadne uznano identyfikację poziomu wiedzy finansowej konsumentów, a w praktyce poziomu ich analfabetyzmu finansowego.

\section{Istota analfabetyzmu finansowego konsumentów}

Jednym z istotnych problemów, jaki występuje na rynku usług finansowych, jest analfabetyzm finansowy konsumentów. Lusardi i Mitchell (2007) definiują to zjawisko jako brak znajomości podstawowych pojęć ekonomicznych potrzebnych do podejmowania racjonalnych decyzji finansowych i decyzji inwestycyjnych dotyczących oszczędzania, zaciągania zobowiązań finansowych, ubezpieczenia się i innych decyzji finansowych. Z kolei Organizacja Współpracy Gospodarczej i Rozwoju (OECD) opisuje analfabetyzm finansowy w trzech aspektach. Zdaniem OECD (2005, s. 24) można uznać za analfabetę finansowego takiego konsumenta, który nie posiada:

a) wiedzy i umiejętności dotyczących oceny ryzyka finansowego i możliwości finansowych;

b) zdolności do identyfikacji możliwości pomocy w sprawach finansowych;

c) zdolności do podjęcia skutecznych działań na rzecz poprawy swojego dobrobytu finansowego.

Można zatem stwierdzić, że konsument nieposiadający odpowiedniej wiedzy finansowej nie jest w stanie sprawnie funkcjonować na rynku usług finansowych. Shambare i Rugimbana (2011) uważają, że podniesienie wiedzy i umiejętności finansowych konsumentów może zapewnić im łagodniejsze przetrwanie okresów kryzysowych występujących w gospodarce. Z kolei Williams i Satchell (2011) twierdzą, że eliminacja analfabetyzmu finansowego może łagodzić skutki słabej ochrony prawnej 
interesów konsumentów na rynku usług finansowych i tym samym ograniczyć konieczność ingerencji państwa w regulacje rynku finansowego. Natomiast Parlament Europejski (2008) wskazuje na fakt, iż wzrost wiedzy finansowej konsumentów może poprawić funkcjonowanie samych rynków finansowych.

Problem analfabetyzmu finansowego stał się w ostatnich latach przedmiotem zainteresowania różnych grup interesu, w tym: rządów, finansistów, a także organizacji zajmujących się ochroną i edukacją rynkową konsumentów. Również z punktu widzenia nauki problem ten stał się ważnym obszarem badań i rozpoznań. Przy czym badania te odnoszą się do różnych aspektów analfabetyzmu finansowego. I tak, pierwszy aspekt dotyczy głównie zdefiniowania tego zjawiska. Według Al-Tamimi i Kalli (2009) analfabetyzm finansowy to brak umiejętności zarządzania finansami osobistymi. Pojęcie to odnoszone jest zatem do braku zdolności konsumenta lub jego niemożności samodzielnego funkcjonowania w odniesieniu do świata finansów i gospodarowania pieniądzem. Jeśli jednak przyjmie się za Melitzem (1970), że pieniądz jest zbiorem symboli, to analfabetyzm finansowym można będzie określić jako brak umiejętności odczytywania i zrozumienia tego symbolu-kodu. Należy w tym miejscu dodać, że znaczenie pieniądza i finansów różni się w różnych społeczeństwach, stąd oceniając analfabetyzm finansowych, należy brać pod uwagę także kontekst kulturowy.

Drugi aspekt badań nad analfabetyzmem konsumenckim odnosi się do relacji pomiędzy poziomem wiedzy finansowej konsumentów i stopniem rozwoju gospodarczego kraju. Przy czym badania przeprowadzone przez OECD w 2005 roku w krajach wysoko rozwiniętych, takich jak: USA, Wielka Brytania, Francja, Australia czy Japonia, a także w krajach rozwijających się wykazały, że poziom wiedzy finansowej większości konsumentów jest bardzo niski (Parlament Europejski, 2008). Potwierdzają to również badania przeprowadzone przez Lusardiego 2008), które ukazały ogromną skalę analfabetyzmu w Stanach Zjednoczonych. Można zatem stwierdzić, że poziom analfabetyzmu finansowego jest niezależny od poziomu rozwoju gospodarczego danego kraju.

Trzeci aspekt badań dotyczy relacji między analfabetyzmem finansowym a zmiennymi demograficznymi konsumentów. Badania przeprowadzone w USA przez Chena i Volpe (1998) pokazały zależności między poziomem znajomości zagadnień finansowych oraz płcią, wiekiem, narodowością, rasą. Badania te uwzględniały także inne zmienne, takie jak poziom dochodów i doświadczenie zawodowe. Wyniki badania pokazały, że czynnikami, które najbardziej różnicują poziom analfabetyzmu finansowego, są: poziom wykształcenia, dochód i doświadczenie zawodowe. Badania również zasygnalizowały, że kobiety miały niższy poziom wiedzy finansowej od mężczyzn. Także obcokrajowcy 
w porównaniu z obywatelami Stanów Zjednoczonych wykazywali się większym analfabetyzmem finansowym. Potwierdzają to również badania zrealizowane przez Volpe, Kotela i Chena (2002), a dotyczące umiejętności inwestycyjnych inwestorów w środowisku wirtualnym. W badaniu tym wykazano, że poziom analfabetyzmu finansowego jest zróżnicowany w zależności od wykształcenia, doświadczenia, wieku, dochodów i płci. I tak, kobiety mają znacznie niższe umiejętności finansowe niż mężczyźni, podobnie jak osoby z krótszym doświadczeniem w świecie inwestycji kapitałowych. Ponadto inwestorzy o wyższych dochodach i wyższym wykształceniu mają większą wiedzę o finansach niż osoby gorzej uposażone i wykształcone. Także badania przeprowadzone w Australii przez agencję AC Nielsen Research (2005) wskazują, że najniższy poziom wiedzy finansowej jest charakterystyczny dla konsumentów o niższym poziomie wykształcenia, bezrobotnych lub niewykwalifikowanych, którzy mają niższe dochody. Można zatem wykazać silny związek pomiędzy poziomem edukacji finansowej i płcią, wykształceniem, poziomem dochodów i doświadczeniem rynkowym konsumenta.

\section{Metodyczne aspekty badania analfabetyzmu finansowego konsumentów w Polsce}

Podejmując badania nad analfabetyzmem finansowym, należy zwrócić uwagę na trudności wynikające ze złożoności samej kategorii, jaką jest analfabetyzm. Badania w tym przypadku wymagają nie tylko odpowiedzi na pytanie, jaki jest poziom analfabetyzmu konsumentów oraz jakie zmienne różnicują to zjawisko. $\mathrm{Na}$ analfabetyzm finansowy trzeba spojrzeć szerzej, z perspektywy zachowań konsumenta na rynku usług finansowych, a w szczególności czynników, które biorą pod uwagę, podejmując decyzje finansowe.

Przed przystąpieniem do badań bezpośrednich dotyczących określenia poziomu i zróżnicowania analfabetyzmu finansowego konsumentów na rynku usług finansowych w Polsce, dokonano głębokich studiów literaturowych w zakresie: wiedzy ekonomicznej konsumentów, zachowań i postaw konsumentów oraz czynników je determinujących, rynków finansowych, jak również metodyki badań rynkowych. Następnie przeprowadzono ogólnopolskie badania bezpośrednie. Badania zrealizowano w ramach grantu Narodowego Centrum Nauki przyznanego na podstawie decyzji nr DEC-2013/11/B/HS4/01470.

Badaniu poddane zostały osoby powyżej 18 roku życia. W badaniach bezpośrednich zastosowano metodę wywiadu kwestionariuszowego. Metoda ta należy do najczęściej 
stosowanych w badaniach rynkowych. Przy konstrukcji samego narzędzia badawczego (kwestionariusza wywiadu) wykorzystano techniki stosowane w badaniach rynkowych i marketingowych. Badania bezpośrednie przeprowadzono na próbie 1200 respondentów we wrześniu 2015 roku. W doborze próby zastosowano procedurę doboru celowego kwotowego. Przyjętymi w badaniu cechami (kwotami) były: wiek i wykształcenie. Do dalszych analiz zakwalifikowano 1047 kwestionariuszy (87,25\% całości próby).

W celu identyfikacji poziomu analfabetyzmu konsumenckiego w Polsce w kwestionariuszu wykorzystano skalę opracowaną przez Monetary Authority w Singapurze (2005), która była weryfikowana na wielu rynkach zagranicznych. Skala umiejętności finansowych obejmowała główne aspekty decyzji finansowych.

\section{Poziom i zróżnicowanie analfabetyzmu finansowego konsumentów w Polsce}

Na podstawie przeprowadzonych badań można stwierdzić, że prawidłowo na pytania zadane w teście MAS odpowiedziało zaledwie 43,95\% respondentów. Zatem mniej niż połowa respondentów wykazuje się odpowiednią wiedzą finansową w Polsce. Należy więc stwierdzić, że poziom analfabetyzmu finansowego w Polsce jest wysoki i wynosi około $56 \%$.

Badania pokazują znaczne różnice w poziomie analfabetyzmu finansowego w zależności od płci, aktywności zawodowej i wykształcenia konsumenta. Natomiast takie zmienne, jak: wiek konsumenta, aktywność zawodowa i sytuacja materialna, nie różnicują poziomu wiedzy finansowej.

Tabela 1. Analfabetyzm finansowy a zmienne demograficzne i ekonomiczne test ANOVA

\begin{tabular}{|l|c|c|c|c|c|}
\hline \multicolumn{1}{|c|}{ Zmienne } & $\chi^{2}$ & $\boldsymbol{d f}$ & $\chi^{2} / \boldsymbol{d f}$ & $\boldsymbol{F}$ & Sig. \\
\hline Płeć & 118,7 & 1 & 118,7 & 5,102 & 0,024 \\
\hline Wiek & 180,4 & 3 & 060,1 & 1,798 & 0,142 \\
\hline Wykształcenie & 109,3 & 4 & 027,3 & 3,904 & 0,006 \\
\hline Zatrudnienie & 299,6 & 1 & 299,6 & 1,531 & 0,000 \\
\hline Aktywność zawodowa & 151,7 & 6 & 025,2 & 6,728 & 0,315 \\
\hline Sytuacja ekonomiczna & 311,5 & 3 & 103,8 & 0,983 & 0,397 \\
\hline
\end{tabular}

Źródło: opracowanie własne.

Jak wskazano wcześniej, podejmując się próby oceny analfabetyzmu polskich konsumentów, trzeba zwrócić uwagę również na czynniki, które biorą pod uwagę 
konsumenci przy podejmowaniu ostatecznych decyzji na rynku usług finansowych. Badania pokazują, że najważniejszą grupą czynników kształtującą decyzje finansowe konsumentów są osobiste potrzeby finansowe konsumenta. W dalszej kolejności są to: informacje nieformalne, niezależne źródła informacji oraz oficjalna informacja finansowa. W najmniejszym stopniu na ostateczne decyzje finansowe konsumentów mają wpływ czynniki określane jako elementy wizerunku danej instytucji finansowej.

W tabeli 2 ujęto zmienne w ramach poszczególnych grup czynników determinujących decyzje finansowe konsumentów.

Tabela 2. Zmienne determinujące decyzje finansowe konsumentów

\begin{tabular}{|c|c|c|}
\hline Numer & Zmienna & Średnia \\
\hline \multicolumn{3}{|c|}{ I. Wizerunek instytucji finansowej } \\
\hline 1. & Stosunek do instytucji finansowej & 3,91 \\
\hline 2. & Reputacja instytucji finansowej & 4,35 \\
\hline 3. & Pozycja instytucji finansowej na rynku & 3,23 \\
\hline 4. & Zasady etyczne realizowane przez instytucję finansową & 3,05 \\
\hline 5. & $\begin{array}{l}\text { Zaangażowanie instytucji finansowej w rozwiązywanie } \\
\text { problemów społecznych }\end{array}$ & 3,17 \\
\hline \multicolumn{3}{|c|}{ II. Informacja finansowa } \\
\hline 6. & Dotychczasowa działalność instytucji finansowej & 3,28 \\
\hline 7. & Notowania giełdowe & 2,37 \\
\hline 8. & Sprawozdania finansowe & 2,86 \\
\hline 9. & Informacje pozyskane $\mathrm{z}$ internetu & 3,24 \\
\hline 10. & Dokumenty wewnętrzne & 2,93 \\
\hline \multicolumn{3}{|c|}{ III. Informacje niezależne } \\
\hline 11. & Statystyki rządowe & 3,41 \\
\hline 12. & Indeksy giełdowe & 3,45 \\
\hline 13. & Informacje $\mathrm{w}$ prasie $\mathrm{i}$ innych mediach & 3,06 \\
\hline 14. & Wypowiedzi przedstawicieli nadzoru finansowego & 3,21 \\
\hline 15. & Wskaźniki ekonomiczne & 3,52 \\
\hline \multicolumn{3}{|c|}{ IV. Informacja nieformalna } \\
\hline 16. & Rekomendacje doradcy finansowego & 3,09 \\
\hline 17. & Opinie członków rodziny & 3,87 \\
\hline 18. & Opinie przyjaciół/znajomych & 3,89 \\
\hline 19. & Opinie pracowników instytucji finansowej & 3,99 \\
\hline 20. & Pogłoski/plotki & 4,02 \\
\hline \multicolumn{3}{|c|}{ V. Osobiste potrzeby finansowe } \\
\hline 21. & Potrzeba dywersyfikacji ryzyka & 3,31 \\
\hline 22. & Łatwość w pozyskaniu środków finansowych & 4,17 \\
\hline 23. & Minimalizacja ryzyka & 3,28 \\
\hline 24. & Przewidywane straty & 3,17 \\
\hline 25. & Maksymalizacja zarobków & 3,40 \\
\hline
\end{tabular}

Źródło: opracowanie własne. 
Na podstawie przeprowadzonych badań można stwierdzić, że konsumenci, podejmując decyzje finansowe, kierują się przede wszystkim: reputacją instytucji finansowej (4,35 pkt), łatwością pozyskania środków finansowych (4,17 pkt), pogłoskami (4,02 pkt), opiniami pracowników instytucji finansowej (3,99 pkt), stosunkiem do instytucji finansowej (3,91 pkt), opinią znajomych (3,89 pkt) i opiniami rodziny ( 3,87 pkt). Z kolei czynnikami, które zgodnie z odpowiedziami respondentów w najmniejszym stopniu wpływają na ich decyzje na rynku usług finansowych, są: oficjalne dokumenty instytucji finansowej (2,93 pkt), sprawozdania finansowe (2,86 pkt) oraz notowania giełdowe $(2,37 \mathrm{pkt})$.

W celu określenia związku między poziomem analfabetyzmu finansowego a czynnikami ostatecznie kształtującymi zachowania konsumentów na rynku usług finansowych, i w konsekwencji decyzjami finansowymi konsumentów, zastosowano metodę regresji. Przy czym czynniki kształtujące decyzje finansowe były traktowane jako zmienna zależna, natomiast umiejętności finansowe jako zmienna niezależna. Wyniki analiz wskazują na znaczącą negatywną relację pomiędzy umiejętnościami finansowymi a czynnikami branymi pod uwagę przy podejmowaniu decyzji finansowych przez konsumentów. Tylko w niewielkim stopniu brane pod uwagę przez konsumenta czynniki można wyjaśnić poziomem umiejętności finansowych.

Tabela 3. Analiza regresji czynników determinujących decyzje finansowe i umiejętności finansowe

\begin{tabular}{|l|c|c|c|c|c|}
\hline \multicolumn{1}{|c|}{ Zmienne zależne } & $\boldsymbol{R}^{\mathbf{2}}$ & Skorygowany $\boldsymbol{R}^{\mathbf{2}}$ & $\boldsymbol{B}$ & $\boldsymbol{t}$ & Sig. \\
\hline Wizerunek instytucji & 0,026 & 0,023 & $-0,223$ & $-0,174$ & 0,012 \\
\hline Informacje niezależne & 0,016 & 0,009 & $-0,301$ & 0,069 & 0,006 \\
\hline Informacje finansowe & 0,000 & $-0,007$ & 0,008 & $-2,334$ & 0,847 \\
\hline Osobiste potrzeby finansowe & 0,021 & 0,015 & $-0,129$ & $-3,259$ & 0,019 \\
\hline Informacje nieformalne & 0,037 & 0,033 & $-0,114$ & $-2,372$ & 0,016 \\
\hline Suma czynników & 0,034 & 0,029 & $-0,166$ & $-2,393$ & 0,007 \\
\hline
\end{tabular}

Źródło: opracowanie własne.

Warto zwrócić uwagę także na fakt, iż występuje negatywny związek między poziomem wiedzy finansowej a kierowaniem się przez konsumenta czynnikami określanymi jako wizerunek instytucji finansowej, podobnie jak: informacjami niezależnymi, indywidualnymi potrzebami finansowymi i informacjami nieformalnymi. Natomiast relacje między umiejętnościami finansowymi a oficjalnymi informacjami finansowymi mają nieznacznie pozytywny charakter. Oznacza to, że analfabetyzm finansowy konsumentów sprzyja temu, by w decyzjach finansowych 
kierowali się oni pozafinansowymi przesłankami, takimi jaki reputacja instytucji finansowej na rynku, informacje od znajomych i rodziny czy też wyłącznie własne potrzeby. Można jednak przypuszczać, że wzrost poziomu wiedzy finansowej może zwiększyć zainteresowanie bardziej obiektywnymi, fachowymi źródłami informacji, jakimi są statystyki finansowe.

Rysunek 1. Subiektywna ocena poziomu wiedzy konsumentów o rynku usług finansowych w Polsce

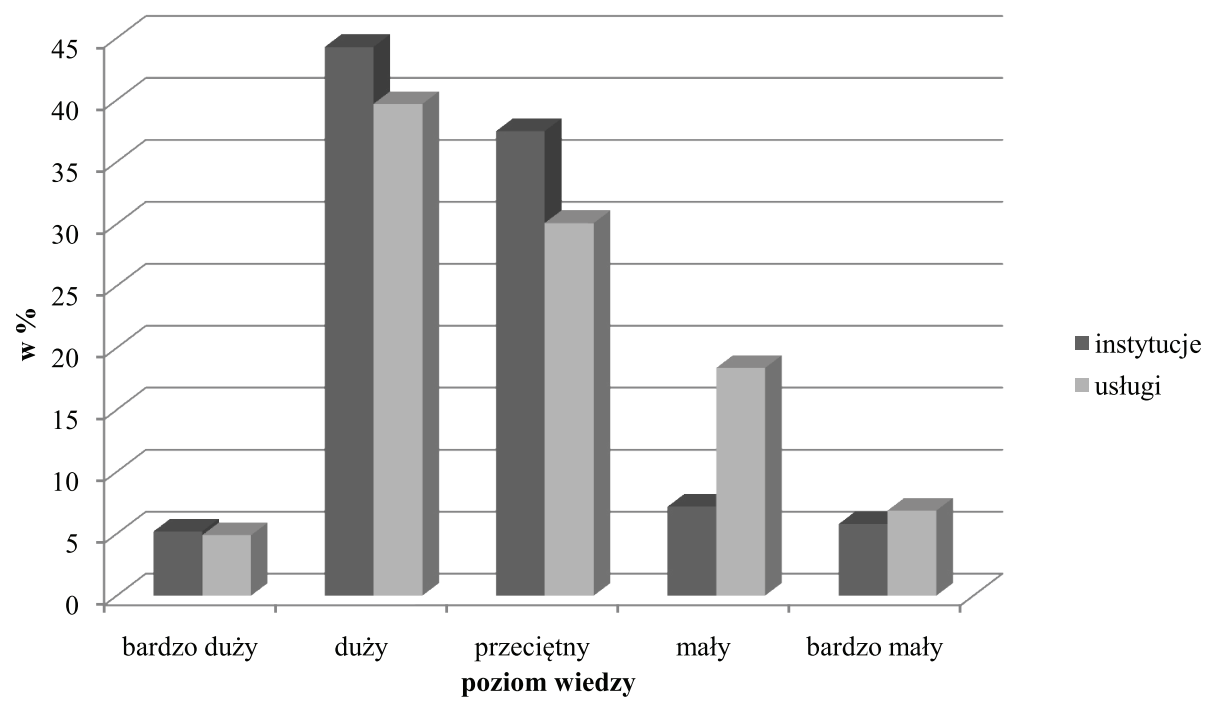

Źródło: opracowanie własne.

Problem analfabetyzmu finansowego może być bardzo trudy do wyeliminowania na polskim rynku usług finansowych. Stosunkowo wysoki poziom tego zjawiska kontrastuje z subiektywnymi opiniami konsumentów o ich dużej wiedzy o rynku usług finansowych, podmiotach na nim działających, ich ofercie itp. Wyniki badań pokazują bowiem, że konsumenci subiektywnie oceniają swoją wiedzę o rynku usług finansowych w Polsce na stosunkowo wysokim poziomie. Prawie połowa respondentów twierdzi, iż dobrze lub bardzo dobrze zna instytucje finansowe działające na naszym rynku. Tyle samo respondentów uważa, że posiada wysoki poziom wiedzy o ofercie rynkowej tych instytucji. Tylko nieznaczna część respondentów ocenia swoją wiedzę w tym zakresie jako bardzo małą. 
Z badań wynika, że konsumenci na rynku usług finansowych nie mają wykształconego nawyku rozpoznawania sytuacji na nim panującej i wynikających z tego tytułu zagrożeń. Nie szukają aktywnie informacji o poszczególnych instytucjach finansowcy $i$ ich ofercie rynkowej. Warto w tym miejscu podkreślić, iż zaledwie $6,1 \%$ respondentów stara się zebrać informacje $\mathrm{z}$ więcej niż jednego źródła.

Przeprowadzone badania pokazują, iż konsumenci nie znają regulacji prawnych związanych z korzystaniem z poszczególnych usług finansowych. Nie czytają oni umów $(59,8 \%$ ) ani regulaminów (prawie $70 \%$ ) przed ich podpisaniem. Głównym powodem jest pośpiech, jaki towarzyszy załatwianiu formalności (41,7\%). Często konsumenci nie czytają tych dokumentów, gdyż są one zbyt długie $(33,2 \%)$, lub dlatego, że napisane są bardzo trudnym (niezrozumiałym dla nich) językiem (30,4\%). Warto również dodać, iż dla około $15 \%$ respondentów przyczyną takiego postępowania jest zaufanie do danej instytucji finansowej.

\section{Podsumowanie}

Mając na uwadze powyższe, można stwierdzić, że poziom wiedzy finansowej konsumentów w Polsce jest niski, a wręcz znaczną część polskich konsumentów cechuje analfabetyzm finansowy. Świadczy o tym fakt, iż decyzje finansowe konsumenci podejmują głównie na podstawie informacji nieformalnej. Zdecydowanie rzadziej korzystają oni z rzetelnych i obiektywnych informacji finansowych płynących z rynku, które wymagają jednak większego poziomu wiedzy i umiejętności finansowych. Konsumenci nie znają regulacji prawnych dotyczących poszczególnych usług finansowych. Poziom analfabetyzmu finansowego kontrastuje z subiektywną opinią konsumentów o ich dużej wiedzy o instytucjach finansowych i oferowanych przez nie usługach.

\section{Literatura}

Al-Tamimi, H., Kalli, H.A. (2009). Financial Literacy and Investment Decisions of UAE Investors. The Journal of Risk Finance, 10, 5, 500-516.

ANZ Survey of Adult Financial Literacy in Australia: Final Report (2005). Melbourne: ACNielsen Research.

Chen, H., Volpe, R. (1998). An Analysis of Personal Financial Literacy among College Students. Financial Services Review, 7, 2, 107-128. 
Improving Financial Literacy: Analysis of Issuers and Policies (2005). Paris: OECD.

Lusardi, A. (2008). Household Saving Behaviour: The Role of Financial Literacy, Information, and Financial Education Programs. Pobrane z: http://www.ssrn.com/abstract $=1094102$ (11.02.2016).

Lusardi, A., Mitchell, O.S. (2007). Financial Literacy and Retirement Preparedness: Evidence and Implications for Financial Education. Business Economics, 42, 1, 35-44.

Melitz, J. (1970). The Polanyi School of Anthropology on Money: An Economist's View. American Anthropologist. New Series, 72, 5, 1020-1040.

Parlament Europejski (2008). Improving Consumer Education and Awareness on Credit and Finance. Official Journal of the European Union, P6_TA(2008)0539.

Quantitative Research on Financial Literacy Levels in Singapore (2005). Singapore: Singapore Monetary Authority of Singapore.

Shambare, R., Rugimbana, R. (2011). Financial Literacy: Implications for South African Microfinance Providers. Wellington: Proceedings of MAG Scholar Conference.

Volpe, R., Kotel, J., Chen, H. (2002). A Survey of Investment Literacy among Online Investors. Financial Counseling and Planning, 13, 1, 11-15.

Williams, O.J., Satchell, S.E. (2011). Social Welfare Issues of Financial Literacy and Their Implications for Regulation. Journal of Regulatory Economics, 40, 1, 1-40.

\title{
FINANCIAL KNOWLEDGE AND CONSUMERS' FINANCIAL ILLITERACY ON FINANCIAL SERVICES MARKET
}

\begin{abstract}
It the article the problem of identification of the level of consumers' financial literacy in Poland was undertaken. The results of research shows that the level of financial literacy of consumers is low and even a large part of Polish consumers are characterized by financial illiteracy. It evidenced by the fact that consumers make financial decisions mostly on informal information sources. Much less frequently consumers benefit from reliable and objective financial information coming from the market, which, however, requires a greater level of knowledge and financial skills. Research shows also that consumers do not know the regulations concerning the various financial services. The level of financial illiteracy is in contrast to the subjective opinion of consumers about their extensive knowledge of financial institutions and the services they offer.
\end{abstract}

Translated by Stawomir Smyczek

Keywords: financial knowledge, financial illiteracy, financial services

JEL Code: D11 